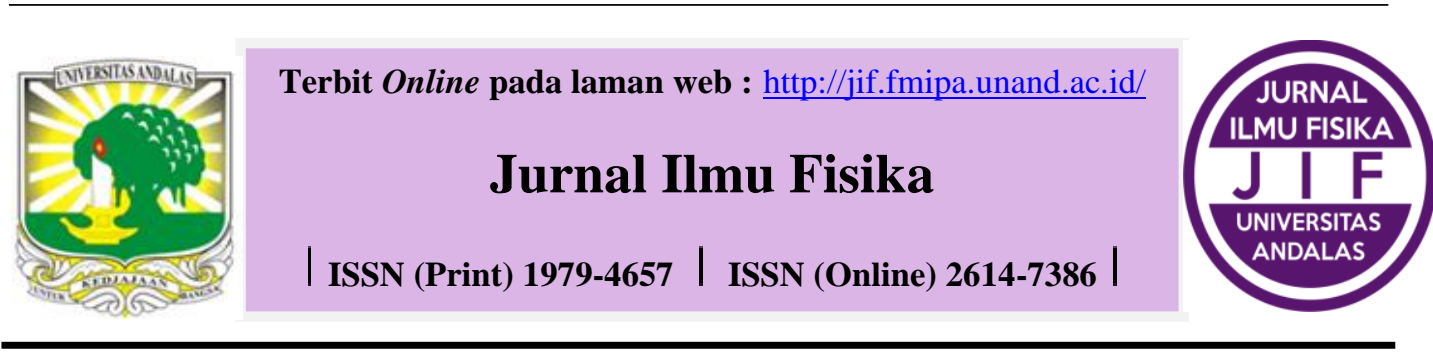

\title{
IDENTIFIKASI ANOMALI SINYAL GEOMAGNETIK ULTRA LOW FREQUENCY SEBAGAI PREKURSOR GEMPA BUMI DENGAN MAGNITUDO KECIL DI WILAYAH KEPULAUAN NIAS
}

\author{
M. Hamidi ${ }^{1}$, Elistia Liza Namigo ${ }^{1 *}$, Ma'muri Ma'muri ${ }^{2}$ \\ ${ }^{1}$ Laboratorium Fisika Bumi, Jurusan Fisika, FMIPA, Universitas Andalas \\ Kampus Unand, Limau Manis, Padang, 25163 \\ ${ }^{2}$ Badan Meteorologi Klimatologi dan Geofisikai, Padang Panjang, 27118 \\ *Korespondensi ke: elistializanamigo@yahoo.com
}

( Diterima:17 Februari 2018; Direvisi: 23 Februari 2018; Diterbitkan: 01 Maret 2018 )

\begin{abstract}
ABSTRAK
Telah dilakukan identifikasi anomali sinyal geomagnetik frekuensi rendah sebagai prekursor gempa bumi dengan magnitudo kecil di wilayah Kepulauan Nias. Pada penelitian ini digunakan data gempa dari bulan September 2016 hingga bulan Juni 2017 dengan rentang waktu data geomagnetik yang digunakan 30 hari sebelum terjadinya gempa bumi. Data geomagnetik ini adalah data yang terekam oleh sensor Magnetic Acquisition Data System (MAGDAS). Penyeleksian data gempa bumi dilakukan dengan menerapkan persamaan radius daerah persiapan gempa yaitu $\rho=10^{0,4 a M} \mathrm{~km}$. Pengolahan data geomagnetik dilakukan dengan menggunakan metode Power Spectrum Density (PSD) untuk menganalisis rasio komponen $\mathrm{S}_{\mathrm{Z}} / \mathrm{S}_{\mathrm{H}}$ medan magnet bumi dan menggunakan metode Single Station Transfer Function (SSTF) untuk menentukan arah azimuth yang dihasilkan oleh anomali Ultra Low Frequency (ULF). Selanjutnya, untuk memastikan sumber anomali digunakan validasi indeks Disturbance Storm Time (DST). Dari hasil pengamatan diperoleh 3 kejadian gempa bumi dengan anomali ULF sebelum terjadinya gempa. Gempa bumi tersebut adalah gempa 13 Oktober 2016 dengan magnitudo 3,3, gempa 16 November 2016 dengan magnitudo 3,6 dan gempa 16 April 2017 dengan magnitudo 3,2. Lead time anomali ULF untuk ketiga gempa ini memiliki durasi yang lebih pendek dibandingkan dengan lead time anomali ULF untuk gempa bumi dengan magnitudo besar yang pernah terjadi di Pulau Sumatera. Kata kunci: sinyal geomagnetik, ultra low frequency, prekursor, gempa magnitudo kecil, kepulauan nias
\end{abstract}




\begin{abstract}
Low frequency (ULF) geomagnetic signal anomalies as small magnitude earthquakes precursor in Nias Islands region have been identified. This research uses earthquake data which were recorded from September 2016 to June 2017 with geomagnetic data period of 30 days before earthquake. The geomagnetic data were recorded by MAGDAS-9 sensor. Earthquake data were selected by implementing formulation of earthquake preparation radius area, that is $\rho=10^{0,43 M} \mathrm{~km}$. The processing of geomagnetic data were carried out by using of Power Spectrum Density (PSD) method to analyze ratio of component $S_{Z} / S_{H}$ for geomagnetic field and Single Station Transfer Function (SSTF) method to calculate the point of azimuth that come from anomaly of ULF. Furthermore, Disturbance Storm Time index (DST) is used to determine the source of anomaly. From observation that are three events of earthquake come with signs of ULF anomaly were identified. The three earthquake events are of October 13, 2016 with magnitude 3.3, of November 16, 2016 with magnitude 3.6, and of April 16, 2016, with magnitude 3.2. Lead time of the anomalies for the three earthquakes has a shorter duration than earthquakes with large magnitude were happen in Sumatera Island.

Keywords: geomagnetic signal, ultra low frequency, precursors, small magnitude earthquake, nias island
\end{abstract}

\title{
1. PENDAHULUAN
}

Kepulauan Nias merupakan salah satu kepulauan terbesar yang terletak di pesisir barat pulau Sumatera. Secara administratif Kepulauan Nias masuk dalam wilayah provinsi Sumatera Utara dengan posisi geografis $0^{\circ} 12^{\prime}-1^{\circ} 32^{\prime} \mathrm{LU}$ dan $97^{\circ}-98^{\circ} \mathrm{BT}$. Secara tektonik, Kepulauan Nias terletak di daerah subduksi 3 lempeng besar yaitu lempeng Indo-Australia yang bergerak ke utara, lempeng Pasifik yang bergerak ke barat, dan lempeng Eurasia (BPS, 2011). Karena berada di daerah subduksi 3 lempeng, maka Kepulauan Nias dikenal sebagai kepulauan yang berada di daerah gugusan cincin api. Hal inilah yang menyebabkan Kepulauan Nias memiliki tingkat frekuensi gempa bumi cukup tinggi (Hutauruk, 2013).

Menurut data BMKG (2017) selama tahun 2015 telah terjadi sebanyak 45 kejadian gempa bumi di wilayah Kepulauan Nias, dimana 41 gempa bumi merupakan gempa bumi kecil dan sedang. Hal ini menunjukkan bahwa Kepulauan Nias merupakan daerah yang rawan terjadinya gempa sehingga dibutuhkan upaya mitigasi gempa bumi (Malau dan Sitepu, 2016). Salah satu upaya mitigasi tersebut adalah dengan melakukan prediksi terhadap peristiwa gempa yang akan terjadi. Upaya mitigasi berguna untuk mengurangi kerugian yang disebabkan oleh gempa bumi. Menurut Pakpahan dkk., (2014) prediksi gempa bumi dapat dilakukan dengan mengamati kemunculan tanda awal gempa bumi atau dikenal dengan prekursor. Prediksi dilakukan dengan mengamati berbagai parameter seperti parameter geo-atmosferik, geokimia, geodesi, geofisika dan beberapa parameter lainnya. Salah satu parameter geofisika yang sering diamati adalah emisi gelombang elektromagnetik dari kerak bumi yang berasal dari gempa bumi (Fransiska dk., 2013).

Emisi gelombang elektromagnetik dihasilkan oleh proses seismogenik yaitu proses patahnya formasi batuan di daerah tumbukan lempeng yang mengakibatkan terjadinya gempa bumi. Spektrum gelombang elektromagnetik yang dipancarkan pada proses ini dimulai dari frekuensi sangat rendah yaitu Ultra Low Frequency (ULF) hingga frekuensi tinggi yaitu Ultra High Frequency (UHF) (Yumoto dkk., 2007). Dari beberapa spektrum tersebut hanya emisi ULF yang dapat dijadikan sebagai prekursor gempa bumi. Hal ini karena ULF hanya sedikit mengalami atenuasi sehingga mampu merambat ke permukaan 
bumi (Hayakawa dkk., 2000; Kopytenko dkk., 2001; Ahadi dkk., 2013). Pendeteksian anomali emisi ULF biasanya dilakukan dengan menggunakan data geomagnetik pada spektrum frekuensi <0,1 Hz. Pada frekuensi tersebut aktivitas seismogenik sebelum, saat dan setelah gempa dapat diamati (Fraser-Smith dkk., 1990; Hayakawa dkk., 2000).

Dalam menganalisis emisi ULF sebagai prekursor digunakan indeks DST sebagai validasi untuk memastikan penyebab anomali yang terjadi. Indeks DST digunakan untuk mengamati aktivitas geomagnetik yang terekam pada daerah ekuator $\left(0^{\circ} \mathrm{LU}-0^{\circ} \mathrm{LS}\right)$ dan daerah lintang rendah ( $\left.30^{\circ} \mathrm{LU}-30^{\circ} \mathrm{LS}\right)$ (Saroso dkk., 2008; Ahadi dkk., 2013). Untuk menyimpulkan anomali emisi ULF maka harus terlebih dahulu harus dianalisis aktivitas badai matahari global sehingga diketahui apakah anomali yang terjadi benar-benar merupakan efek dari aktivitas seismogenik (Ibrahim dkk., 2012; Ahadi dkk., 2013; 2014).

Ahadi dkk., (2015) telah melakukan penelitian tentang anomali emisi ULF sebagai prekursor gempa bumi kuat yang terjadi selama 2007-2012 di Pulau Sumatera. Penelitian ini dilakukan dengan menggunakan metode PSD untuk menganalisis polarisasi rasio komponen $\mathrm{S}_{\mathrm{Z}} / \mathrm{S}_{\mathrm{H}}$ geomagnetik pada gempa bumi dengan magnitudo $>6$. Hasil dari penelitian mereka menunjukkan bahwa anomali emisi ULF terkait prekursor gempa bumi kuat berada pada frekuensi 0,06 Hz. Pada penelitian tersebut, Ahadi dkk., (2016) menemukan bahwa lead time anomali ULF sebanding dengan magnitudo gempa dan berbanding terbalik dengan jarak hiposenter. Penelitian yang dilakukan di daerah Sumatera lebih sering dilakukan dengan menggunakan data gempa bumi dengan magnitudo >6. Menurut Armansyah dkk., (2016) peluang kejadian gempa bumi dengan magnitudo $<5$ lebih sering terjadi dibandingkan dengan magnitudo $>6$ sehingga dapat dijadikan sebagai acuan untuk melakukan penelitian. Gempa dengan magnitudo <5 menghasilkan emisi ULF yang dapat terdeteksi pada data magnetik bumi dengan kedalaman sumber gempa bumi $<50 \mathrm{~km}$ (Armansyah dkk., 2016). Pada penelitian ini dilakukan identifikasi anomali ULF sebagai prekursor gempa di wilayah Kepulauan Nias dengan magnitudo <5 menggunakan metode Power Spectrum Density (PSD) untuk mengetahui karakteristik dari anomali ULF yang terjadi.

\section{METODE PENELITIAN}

Pada penelitian ini digunakan data geomagnetik komponen $\mathrm{H}$ dan $\mathrm{Z}$ dari bulan Juli 2016 sampai Juni 2017 yang telah terekam oleh MAGDAS-9 milik BMKG Stasiun Kelas III Gunung Sitoli, Kepulauan Nias, dan data gempa bumi bulan September 2016 hingga Juni 2017 yang terjadi di Wilayah Kepulauan Nias. Pengolahan data geomagnetik terdiri dari 5 tahap, yaitu konversi, koreksi, Polarisasi Spectral Density Ratio, Single Station Tranfer Function, dan identifikasi anomali ULF terkait prekursor gempa bumi. Data gempa bumi diseleksi berdasarkan daerah persiapan gempa bumi yang dirumuskan oleh Dobrovolsky dkk., (1979) sebagai berikut:

$$
\rho=10^{0,43 M} \mathrm{~km}
$$

\subsection{Konversi data geomagnetik}

Konversi data geomagnetik dilakukan untuk menyesuaikan input data geomagnetik. Konversi ini akan mengubah format data mentah geomagnetik yang semula berektensi*.gsi mejadi file berektensi*.mgd. Kemudian, file ini di akan di konvesi menjadi file ASCII yang berektensi*.gea. 


\subsection{Koreksi data geomagnetik}

Koreksi data geomagnetik ini bergunan untuk menghilangkan noise yang terdapat pada data, sehingga didapatkan kualitas hasil data yang lebih baik. Koreksi dilakukan dengan mereduksi spike like noise dan artifisial noise data menggunakan metode diff. Kemudian dihitung trend correction untuk data harian untuk mendapatkan data harian yang lengkap untuk masing-masing komponen. Setelah itu, dilakukan penerapan bandpass filter pada rentang frekuensi 0,002-0,005 Hz.

\subsection{Polarisasi Spectral Density Ratio}

Polarisasi ini berguna untuk melihat spektrum anomali komponen $\mathrm{H}$ dan $\mathrm{Z}$ dari data geomagnetik. Polarisasi dilakukan dengan mengubah data dari domain waktu ke domain frekuensi menggunakan Fast Fourier Transform (FFT). Untuk mencari polarisasi rasio $\mathrm{S}_{\mathrm{Z}} / \mathrm{S}_{\mathrm{H}}$ dapat dilakukan dengan menggunakan persamaan berikut:

$$
P_{\text {Day }}=\frac{z_{\text {Day }}}{H_{\text {Day }}}
$$

Kemudian, setelah didapat nilai rasio PSD komponen $\mathrm{S}_{\mathrm{Z}} / \mathrm{S}_{\mathrm{H}}$ data, nilai tersebut diubah dari domain frekuensi kembali ke domain waktu.

\subsection{Single Station Transfer Function (SSTF)}

Single Station Transfer Function merupakan metode yang digunakan untuk meilihat arah (Azimuth) dari sumber anomali ULF yang terjadi dengan menggunakan persamaan sebagai berikut.

$$
\theta=\arctan \left(\frac{B(\omega)}{A(\omega)}\right)
$$

Keluaran dari STTF berupa grafik kuadran yang kemudian diplot ke peta dengan posisi nol grafik merupakan letak sensor MAGDAS-9. Menurut Ahadi dkk., (2014), anomali ULF dapat dikategorikan sebagai prekursor jika menunjukkan azimuth ke arah posisi episenter gempa bumi dengan toleransi $25^{\circ}$ ke arah atas dan ke arah bawah azimuth sebenarnya.

\subsection{Identifikasi Anomali ULF Terkait Prekursor}

Identifikasi anomali ULF terkait gempa bumi dapat dilakukan dengan melihat nilai $\mathrm{S}_{\mathrm{H}}$ dan $\mathrm{S}_{\mathrm{Z}}$ yang melewati batas nilai standar deviasi data. Identifikasi dilakukan dengan terlebih dahulu membuat standar deviasi data hasil pengolahan menggunakan moving average data geomagnetik $\mathrm{S}_{\mathrm{Z}} / \mathrm{S}_{\mathrm{H}}$ perhari.

\section{HASIL DAN DISKUSI}

\subsection{Hasil Penyeleksian Event Gempa Bumi}

Dalam kurun waktu dari bulan September 2016 hingga Juni 2017 terdapat 16 gempa bumi yang terjadi di wilayah kepulauan Nias dengan karakteristik $3<\mathrm{Mw}<5$ dan kedalaman $<60 \mathrm{~km}$. Terdapat 3 kejadian gempa bumi yang memenuhi radius persiapan gempa bumi berdasarkan Persamaan 1. Data gempa tersebut dapat dilihat pada Tabel 1.

Table 1 Data yang digunakan dalam penelitian 


\begin{tabular}{lccccc}
\hline Tanggal & Waktu & Latitude & Longitude & Kedalaman & Magnitudo \\
\hline $2016-10-13$ & $03: 11: 12,9$ & 1,24 & 97,39 & 39 & 3,3 \\
$2016-11-16$ & $04: 41: 18,8$ & 1 & 97,47 & 19 & 3,6 \\
$2017-04-16$ & $19: 48: 15,5$ & 1,29 & 97,7 & 36 & 3,2 \\
\hline
\end{tabular}

\subsection{Hasil Analisis Emisi ULF terkait Gempa Bumi di Wilayah Kepulauan Nias}

\subsubsection{Prekursor Gempa Bumi 13 Oktober 2016}

Polarisasi rasio $S_{Z} / S_{H} 30$ hari sebelum gempa bumi 13 Oktober 2016 menunjukkan terjadi 4 kali anomali ULF. Dari empat anomali ULF hanya anomali keempat yaitu pada tanggal 09 Oktober 2016 yang dapat dianggap sebagai prekursor gempa bumi ditunjukkan oleh Gambar 1(a). Anomali tersebut menunjukkan azimuth sebesar $254,757^{\circ}$ ke arah episenter gempa bumi 13 Oktober 2016 seperti dapat dilihat pada Gambar 1(b).

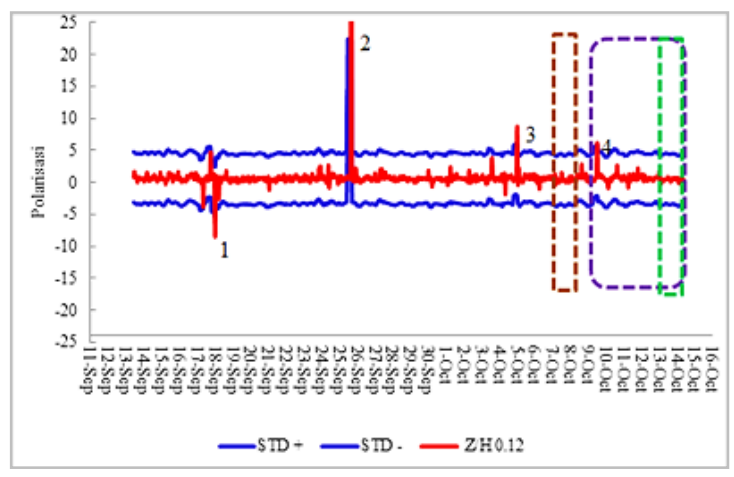

Gambar 1 (a) Grafik anomali ULF hasil polarisasi rasio SZ/SH sebagai prekursor gempa bumi 13 Oktober 2016. Rentang waktu onset time (garis ungu) ke waktu terjadinya gempa bumi (garis hijau). Terjadi gempa bumi pada tanggal 07 Oktober 2016 (garis coklat). (b) Posisi episenter gempa bumi 13 Oktober 2016 (bintang merah), dengan jarak $21 \mathrm{~km}$ dari sensor MAGDAS-9 Gunungsitoli (segitiga kuning). Azimuth sebenarnya anomali ULF (panah biru) dan azimuth toleransi ULF (garis merah) tanggal 09 Oktober 2016

Anomali yang terjadi divalidasi dengan indeks DST untuk memastikan sumber anomali yang terjadi. Hasil validasi DST menunjukkan tidak terjadi badai magnetik pada saat terjadi anomali ULF sebagai prekursor gempa bumi 13 Oktober 2016 yang ditunjukkan oleh Gambar 2. Onset time anomali ULF sebagai prekursor gempa bumi 13 Oktober 2016 adalah 4 hari sebelum gempa bumi, sedangkan lead time anomali terjadi 1 hari sebelum terjadinya gempa bumi. 


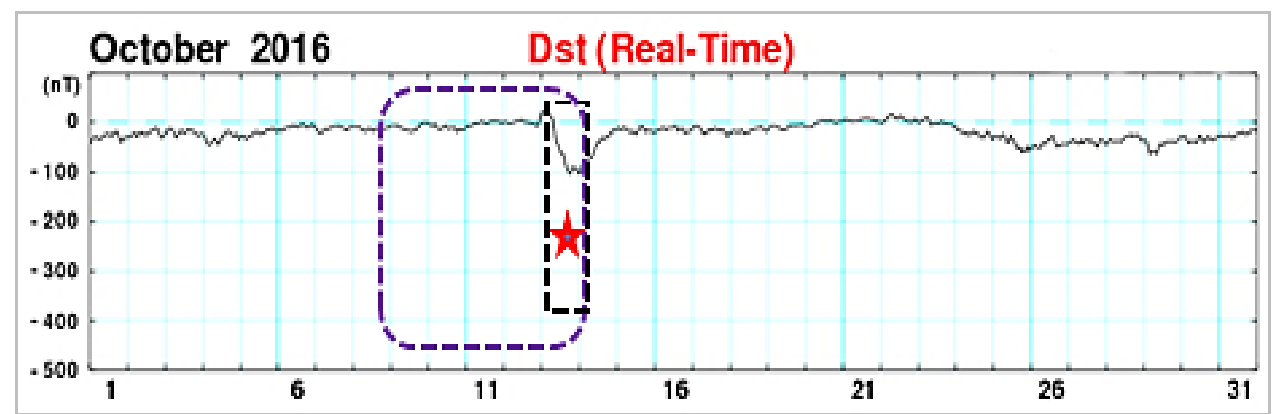

Gambar 2 Nilai indeks DST bulan Oktober 2016. Rentang waktu terjadinya anomali ULF (garis ungu) tanggal 09 Oktober 2016 sampai terjadinya gempa bumi (bintang merah) dan badai magnetik pada hari terjadinya gempa bumi (garis hitam)

\subsubsection{Prekursor Gempa Bumi 16 November 2016}

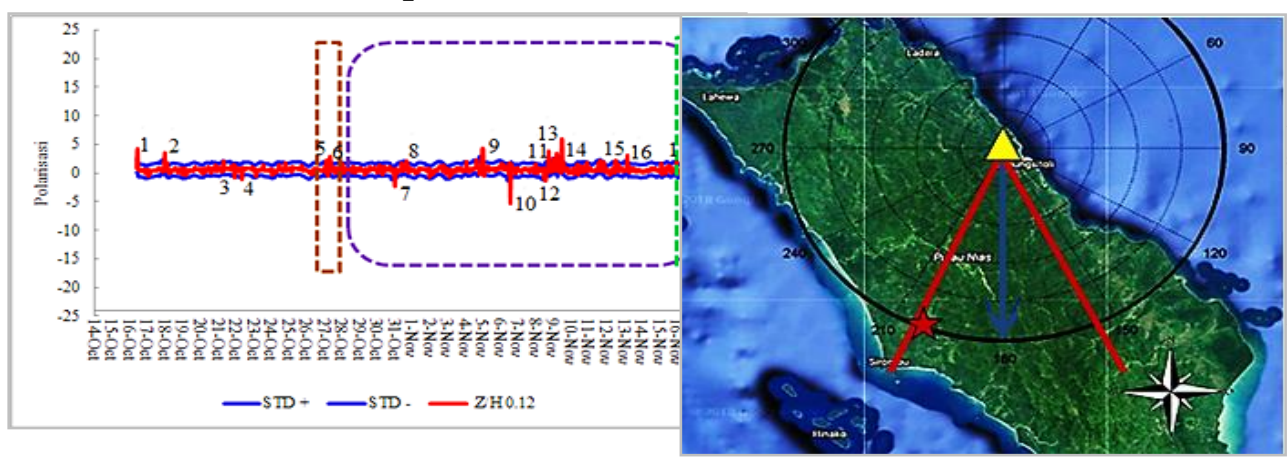

Gambar 3 Grafik polarisasi rasio $\mathrm{S}_{\mathrm{Z}} / \mathrm{S}_{\mathrm{H}}$ sebelum gempa bumi 13 Oktober 2016 menunjukkan terjadi 17 kali anomali ULF (a) Posisi episenter gempa bumi 13 Oktober 2016 berada masih dalam daerah azimuth (b)

Grafik polarisasi rasio $\mathrm{S}_{\mathrm{Z}} / \mathrm{S}_{\mathrm{H}}$ sebelum gempa bumi 13 Oktober 2016 menunjukkan terjadi 17 kali anomali ULF yang dapat dilihat pada Gambar 3(a). Dari 17 anomali yang terjadi hanya 5 anomali yang bisa dijadikan sebagai prekursor gempa bumi yaitu anomali tanggal 05, 08, 09, 12 dan 15 November 2016. Azimuth dari onset time anomali yang terjadi adalah sebesar $180,883^{\circ}$, dengan Posisi episenter gempa bumi 13 Oktober 2016 berada masih dalam daerah azimuth toleransi yang dapat dilihat pada Gambar 3(b).

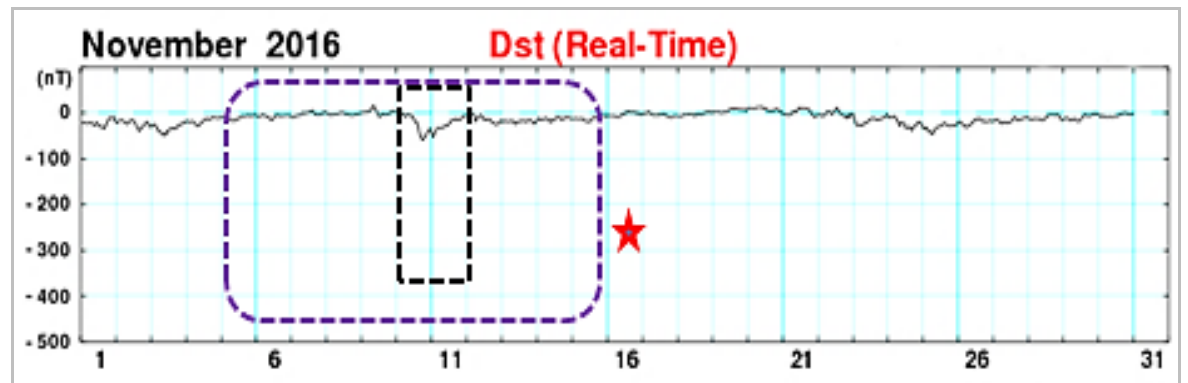

Gambar 4 Nilai indeks DST bulan November 2016. rentang waktu terjadinya anomali ULF (garis ungu) tanggal 05 November 2016 sampai terjadinya gempa bumi (bintang merah) dan badai magnetik pada hari terjadinya gempa bumi (garis hitam)

58 DOI: $\underline{10.25077 / j i f .10 .1 .53-62.2018}$

Hamidi,dkk 
Hasil validasi DST bulan November 2016 menunjukkan terjadi dua kali badai magnetik yaitu pada tanggal 10 dan 11 November 2016, dengan intensitas masing-masing sebesar $59 \mathrm{nT}$ dan $53 \mathrm{nT}$ yang dapat dilihat pada Gambar 4. Badai magnetik tersebut merupakan badai magnetik tipe lemah tidak mempengaruhi anomali ULF, sesuai dengan klasifikasi indeks DST menurut Loewe dan Prolss (1997). Hal ini karena waktu badai magnetik tidak sama dengan waktu anomali ULF sebagai prekursor. Onset time dari anomali adalah 12 hari sebelum gempa, sedangkan lead time anomali selama 5 hari sebalum gempa bumi terjadi.

\subsubsection{Prekursor Gempa Bumi 16 April 2017}

Polarisasi rasio $\mathrm{S}_{Z} / \mathrm{S}_{\mathrm{H}} 30$ hari sebelum gempa bumi 13 Oktober 2016 menunjukkan terjadi 12 kali anomali ULF seperti dapat dilihat pada gambar 5(a). Dari 12 anomali hanya anomali yang terjadi pada tanggal 03 dan 16 April 2017 yang dapat dianggap sebagai prekursor gempa. Azimuth dari onset time anomali adalah sebesar 94,613 ${ }^{\circ}$. Azimuth tersebut tepat menunjuk ke arah episenter gempa bumi 16 April 2017 seperti dapat dilihat pada Gambar 5(b).

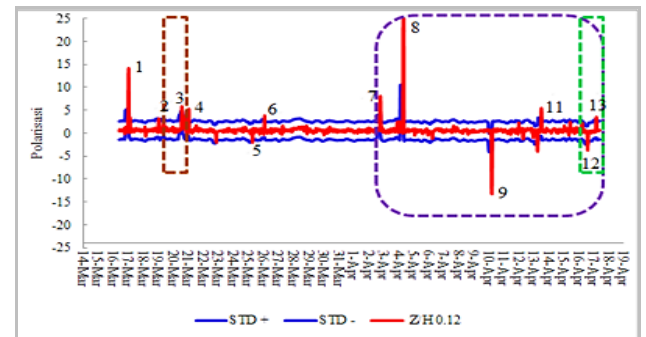

(a)

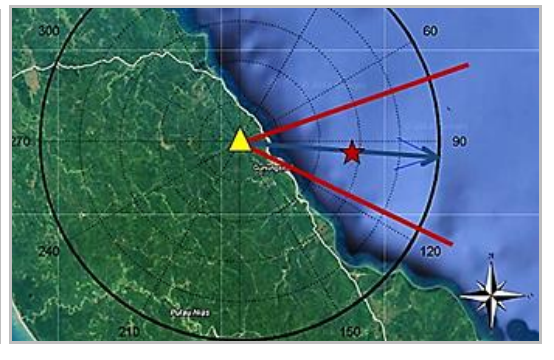

(a)

Gambar 5 (a) Grafik anomali ULF hasil polarisasi rasio $\mathrm{S}_{\mathrm{Z}} / \mathrm{S}_{\mathrm{H}}$ sebagai prekursor gempa bumi tanggal 16 April 2017. Rentang waktu onset time (garis ungu) ke waktu terjadinya gempa bumi (garis hijau). Terjadi gempa bumi pada tanggal 19 Maret 2017 (garis coklat) sebelum terjadinya gempa bumi terpilih. (b) Posisi episenter gempa bumi 16 April 2017 (bintang merah), dengan jarak $13 \mathrm{~km}$ dari sensor MAGDAS-9 Gunungsitoli (segitiga kuning). Azimuth sebenarnya anomali ULF (panah biru) dan azimuth toleransi ULF (garis merah) tanggal 03 April 2017

Hasil validasi DST bulan April 2017 menunjukkan terjadi satu kali badai magnetik yaitu pada tanggal 04 April 2017, dengan intensitas sebesar -44 nT. Badai magnetik tersebut merupakan badai magnetik tipe lemah yang tidak mempengaruhi anomali ULF, karena waktu badai magnetik yang tidak sama dengan anomali ULF. Badai tersebut dapat dilihat pada Gambar 6. Onset time anomali terjadi 13 hari sebelum terrjadinya gempa bumi, sedangkan lead time anomali adalah selama 2 hari. 


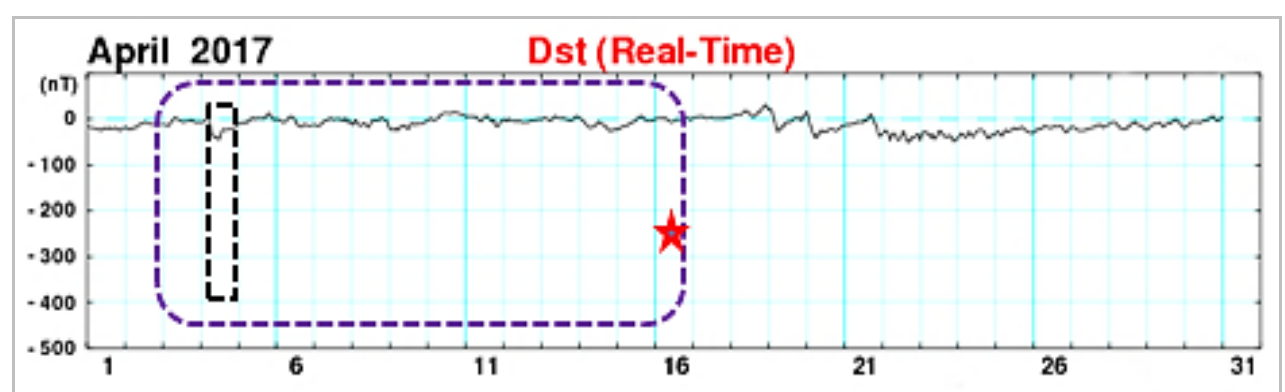

Gambar 6 Nilai indeks DST bulan November 2016. rentang waktu terjadinya anomali ULF (garis ungu) tanggal 05 November 2016 sampai terjadinya gempa bumi (bintang merah) dan badai magnetik pada hari terjadinya gempa bumi (garis hitam)

Anomali ULF sebagai prekursor gempa bumi yang terjadi di Wilayah Kepulauan Nias memiliki lead time yang berbeda-beda. Lead time anomali ULF tersebut dipengaruhi oleh magnitudo dan jarak hiposenter gempa ke sensor. Lead time yang didapatkan memiliki durasi waktu yang lebih pendek dibandingkan dengan penelitian sebelumya, karena magnitudo gempa bumi yang teliti merupakan gempa bumi dengan magnitudo kecil. Selain itu, anomali ULF prekursor gempa 16 April 2017 dengan magnitudo 3,2 memiliki lead time yang lebih lama dibandingkan dengan prekursor gempa 13 November 2016 dengan magnitudo 3,3. Hal ini karena jarak hiposenter gempa 16 April yang memiliki jarak yang lebih dekat ke sensor dibadingkan dengan gempa 13 November 2016. Gempa 16 April 2017 memiliki jarak $13 \mathrm{~km}$ dari sensor, sedangkan gempa 13 November memiliki jarak $21 \mathrm{~km}$. Sehingga disimpulkan bahwa lead time anomali ULF memiliki durasi waktu yang bergantung pada besarnya magnitudo gempa bumi dan jarak hiposenter gempa bumi ke sensor. Semakin besar magnitudo gempa maka lead time anomali ULF akan semakin semakin lama, semakin jauh jarak hiposeneter gempa ke sensor maka lead time anomali ULF akan semakin kecil, sesuai dengan penelitian yang telah dilakukan oleh Ahadi dkk., (2015).

\section{KESIMPULAN}

Penelitian ini memperlihatkan bahwa untuk gempa bumi yang terjadi di wilayah Kepulaun Nias dalam rentang waktu dari September 2016 hingga Juni 2017dengan magnitudo $3<\mathrm{Mw}<5$ yaitu gempa 13 Oktober 2016, 16 November 2016 dan 16 April 2017, terdeteksi keberadaan anomali sinyal ULF. Lead time prekursor gempa 13 Oktober 2016 terjadi selama 1 hari sebelum terjadi gempa bumi. Untuk gempa 16 November 2016 terjadi selama 5 hari sebelum terjadi gempa bumi, sedangkan untuk gempa 16 April 2017 terjadi selama 2 hari sebelum gempa bumi. Onset time prekursor gempa 13 Oktober 2016 muncul pada 4 hari sebelum terjadinya gempa dengan azimuth $254,757^{\circ}$. Untuk gempa 16 November 2016 onset time muncul pada 12 hari sebelum terjadinya gempa bumi dengan azimuth $180,883^{\circ}$, sedangkan gempa 16 April 2017 onset time muncul pada 13 hari sebelum terjadinya gempa dengan azimuth $94,613^{\circ}$ 


\section{DAFTAR PUSTAKA}

1. Ahadi, S., Puspito,N.T., Saroso, S., Ibrahim, G., Siswoyo. dan Suhariyadi., 2013, Prekursor Gempa Bumi Padang 2009 Berbasis Analisis Power Rasio dan Fungsi Transfer Tunggal, Jurnal Ilmia Geomatika, Badan Informasi Geospasial, Bogor, hal. 49-56.

2. Ahadi, S., Puspito, N.T., Ibrahim, G. dan Saroso, S., 2014, Determination of The Onset time in Polarization Power Ratio $\mathrm{Z} / \mathrm{H}$ for Precursor of Sumatra Earthquake, AIP Conference Proceedings, American Institute of Physics, Maryland, hal. 75-78.

3. Ahadi, S., Puspito, N.T., Ibrahim, G., Saroso, S., Yumoto K., Yoshikawa, A. dan Muzli., 2015, Anomalous ULF Emission and Their Possible Association with the Strong Earthquakes in Sumatera, Indonesia during 2007-20012, J.Math.Fund.Sci, Institut Teknologi Bandung, Bandung, hal. 84-103.

4. Armansyah., Fatimah, A. dan Ahadi, S., 2016, Studi Anomali Sinyal Magnet Bumi Ultra Low Frequency sebagai Prekursor Gempa Bumi untuk Kasus Kejadian Gempa Bumi dengan Magnitudo Kecil, Proseding Seminar Nasional Fisika dan Aplikasinya, Bale Sawala Kampus Universitas Padjadjaran-Jatinangor.

5. Badan Pusat Statistik, 2011, Nias Dalam Angka 2011, Gunungsitoli, hal. 15.

6. Dobrovolsky, I.R., Zubkov, S.I. dan Myachkin, V.I., 1979, Estimation of The Size of Earthquake Preparation Zone, Pageoph, Birkhauser Verlag, Basel, hal. 1025-1044.

7. Fransiska, N., Setyawan, A. dan Nurdiyanto, B., 2013, Penentuan Prekursor Gempa Bumi Menggunakan Data Magnetotellurik di Daerah Pelabuhan Ratu, Youngster Physics Journal, Universitas Diponegoro, Bandung, hal. 115-120.

8. Fraser-Smith, S.A.C., Bernardy, A., McGill, P.R., Ladd, M.E., Yielliwell, R.A. dan Villard, O.G.Jr., 1990, Low Frequency Magnetic Field Measurements Near The Epicenter of The Ms 7.1 Loma Prieta Earthquake, Geophys. Res. Lett, John Wiley and Sons. Inc, New Jersey, hal. 1465-1468.

9. Hayakawa, M., Itoh, T., Hattori, K. dan Yumoto, K., 2000, ULF Electromagnetic Precursors for an Earthquake at Biak, Indonesia on February 17, 1996, Geophysical. Res, John Wiley and Sons. Inc, New Jersey, hal.15311534.

10. Hutauruk, M. Y., 2015, Pemodelan Gelombang Tsunami Akibat Gempa Bumi Tektonik Dasar Laut di Daerah Pulau Nias dan Sekitarnya, Skripsi S-1, Jurusan Fisika Universiatas Sumatera Utara, Medan.

11. Ibrahim, G., Ahadi, S. dan Saroso, S., 2012, Karakteristik Sinyal Emisi ULF yang Berhubungan dengan Prekursor Gempa Bumi di Sumatera, Studi Kasus: Gempa Bumi Padang 2009 dan Gempa Bumi Mentawai 2010, Jurnal Meteorologi dan Geofisika, Puslitbang Badan Meteorologi Klimatologi dan Geofisika, Jakarta, hal. 81-89.

12. Kopytenko, Y., Ismagilov, V., Hayakawa, M., Smirnova, N., Troyan, V. dan Peterson, T., 2001, Investigation of The ULF Electromagnetic Phenomena Related to Earthquakes: Contemporary Achievements and The Perspectives, 
Annals of Geophysics, insituto Nazionale di Geofisica e Volcanologia, Bologna, hal. 325-334.

13. Loewe, C. A. dan Prolss, G. W., 1997, Classification and Mean Behaviour of Magnetic Storms, J. Geophys. Res. Univesitas Bonn, Bonn, hal. 1420914213.

14. Malau, N. D, dan Sitepu, M., 2016, Peramalan Terjadinya Gempa Bumi Tektonik untuk Wilayah Pulau Nias Menggunakan Metode Distribusi Weibull dan Eksponensial, Jurnal EduMatSains, Universitas Kristen Indonesia, Jakarta, hal. 15-28

15. Pakpahan, S., Nurdiyanto, B. dan Ngadmanto, D., 2014, Analisis Parameter Geo-Atmosferik dan Geokimia sebagai Prekursor Gempa Bumi di Pelabuhan Ratu, Sukabumi, Jurnal Meteorologi dan Geofisika, Puslitbang Badan Meteorologi Klimatologi dan Geofisika, Jakarta, hal. 77-86.

16. Saroso, S. Hattori, K. Ishikawa, H. Ida Y. Shirogane, R. Hayakawa M. Yumoto, K. Shiokawa, K. dan Nishihashi, M., 2008, ULF Geomagnetic Anomalous Changes Possibly Associated with 2004-2005 Sumatra Earthquake, Physics Chemistery Earth, Elsevier Ltd, New York, hal. 343-349.

17. Yumoto, K., Ikemoto, S., Cardinal, M.G., Kawano, H., Yoshikawa, A., Meda, G.,, Hayakawa, M., Hattori, K., Liu, J.Y., Saroso, S., Husni, M., Widarto, D.S., Ramos, E,G., Otoriy, R.E.S. dan MAGDAS Group., 2007, Space Weather and Seismo Electromagnetic, Electromagnetic in Sesismic and Volcanic Area, ILWS Workshop, Kyusu University, Fukuoka, hal. 19-24.

18. Badan Meteorologi, Klimatologi dan Geogfisika, 2017, Data Repository Gempa, www.repogempa.bmkg.go.id. Diakses Oktober 2017. 